\title{
Multielement Determination in Tobacco Leaves by Instrumental Neutron Activation Analysis
}

\author{
Mo-Hsiung YANG, Shang-Fei LAI* and Si-Jung YEH \\ Institute of Nuclear Science, National Tsing Hua University, \\ Hsinchu, Taiwan, * Atomic Energy Council, \\ Executive Yuan, Republic of China
}

Received November 13, 1972

\begin{abstract}
A neutron activation analysis for the simultaneous determination of multielements in tobacco leaves is descrived. The method is based on high resolution $\mathrm{Ge}(\mathrm{Li})$ spec. trometer coupled to a computerized data reduction system. By selecting a suitable irradiation-cooling-counting system 13 elements in tobacco leaves were quantitatively determined without any chemical separation. Most of the photopeaks employed in the analysis were found to be free of spectral interferences. The detection limits of the elements to be determined in tobacco leaves under the present irradiation and counting conditions were evaluated. Several elements showed somewhat higher fluctuation in tobacco leaves of different origin.
\end{abstract}

\section{Introduction}

For many years, neutron activation analysis has been applied in various areas of scientific investigation on account of its high sensitivity. Recent development on high resolution solid state radiation detector has provided significant advantages to nondestructive trace determination ${ }^{1,2}$. With this improved technique the determination of trace quantities of multielements can be carried out without involving the problem of chemical separation.

Tobacco is one of the most important daily consumptions in modern living. In order to investigate the physiological significance of trace elements in tobacco which may pass via smoke into human body, a study to pursue the nature and quantities of elements presented in tobacco leaves, especially those of toxic ones such as $\mathbf{H g}$ and As, would be of importance.

Several attempts have been made to combine radiochemical separation method with neutron activation analysis for determining the trace concentration of $\mathrm{Cu}, \mathrm{Hg}$, Se and As in tobacco leaves and products ${ }^{3) \sim 5)}$. Analyses of trace elements in tobacco samples by nondestructive activation analysis using $\mathrm{Ge}(\mathrm{Li})$ detector have also been reported $^{6,7}$.

The present study employed instrumental neutron activation analysis to determine simultaneously the multielements in tobacco leaves by utilizing a high resolution $\mathrm{Ge}(\mathrm{Li})$ spectrometer coupled with computerized data reduction system. To avoid unnecessary interferences, a suitable irradiation-coolingcounting system was chosen.

\section{Experimental}

2.1 Sample and Standard Preparation

Various kinds of dried tobacco leaves. were obtained from Taiwan Tobacco and Wine Monopoly Bureau. Some of them were imported from the United States of America, Korea and Turkey. No pretreatment was carried out on these samples, except that they were dried in desiccator. About 100-200 $\mathrm{mg}$ of samples was used for each irradiation.

The standards were prepared by dissolving salts of the elements of interest (analytical grade) in distilled water or dilute nitric acid. The concentration of the standard solutions was so adjusted that the activity of each element in $100 \mu l$ of the standard solution was comparable with what may be 
induced in tobacco leave samples.

\subsection{Neutron irradiation}

The high resolution of the $\mathrm{Ge}(\mathrm{Li})$ detector allowed the use of mixed standard solutions which contained known concentrations of all the elements of interest. Samples and standards were sealed in quartz ampoules of the size of $10 \mathrm{~mm} \phi \times 50 \mathrm{~mm}$. A special care was taken to distribute the standard solutions homogeneously in a cellulose matrix so as to keep both the standards and the samples in exactly the same geometrical condition.

Two irradiations were usually made. Care was also exercised to irradiate both the sample and the standard in an identical condition in the nuclear reactor. The first group of sample was irradiated for 10 minutes, together with the other ampoule containing the standards to be determined $(\mathrm{Ca}, \mathrm{Cl}, \mathrm{Mn})$. The second group was irradiated for $12 \mathrm{hrs}$. It consisted of one sample and one ampoule of mixed standard solutions of longer half-lived. Both groups were irradiated at a thermal neutron flux of about $2 \times 10^{12} \mathrm{n} / \mathrm{cm}^{2} / \mathrm{sec}$ in the THOR reactor of National Tsing Hua University.

After irradiation and an appropriate cooling, the surface of irradiated quartz tube was washed with nitric acid to remove possible radioactive contamination. The samples were not removed from the ampoules to prevent possible escape of volatile elements such as $\mathrm{Br}$, As and $\mathrm{Hg}$. Blank test was performed by irradiating quartz ampoule containing equivalent size of cellulose matrix and counted under an identical condition. The results showed no interfering gamma rays for the elements under consideration.

\subsection{Counting and Data Processing}

The activities were measured with the 1,024 channel pulse height analyzer coupled to a $43 \mathrm{cc}$ coaxial $\mathrm{Ge}(\mathrm{Li}$ ) detector (ORTEC Product) which has an energy resolution of $2.5 \mathrm{keV}$ for the $1.33 \mathrm{MeV}$ photopeaks of ${ }^{60} \mathrm{Co}$. Two computer programs written in BASIC language for the HP 5402 MCA/BASIC SYS-
TEM, were designed to process the data. One was for system calibration and the other was for calculating the net peak areas of photopeaks on the spectrum. The latter is successful in those of isolated peaks, but it fails to work reliably in resolving doublets. Fortunately, it is of ten possible to remove contributions from species which have other gamma rays whose photopeak areas can be determined (e.g. photopeaks of ${ }^{76} \mathrm{As}$ and ${ }^{82} \mathrm{Br}$ in Fig. 2).

For the species such as $\mathrm{Cl}, \mathrm{Mn}, \mathrm{La}$ and $\mathrm{Br}$, characterization of the observed gamma rays was based on the energies and half lives of the spectral lines, while for those of very long and very short lived, the former played a more important role. After a 3 minute decay period, a 5 minute count was taken to measure the very short-lived product ${ }^{40} \mathrm{Ca}$ for the 10 minute irradiated sample. No sooner had the data processing of the ${ }^{40} \mathrm{Ca}$ finished, then the sample was recounted for the period of another 10 minutes to obtain the activities of ${ }^{38} \mathrm{Cl}$ and ${ }^{56} \mathrm{Mn}$. For the sample of 12-hour irradiation, the welldefined photopeaks of ${ }^{82} \mathrm{Br},{ }^{140} \mathrm{La}$, and ${ }^{76} \mathrm{As}$ could be obtained after three days' cooling by means of 50 minutes' counting. The sample was now allowed to decay for an additional two weeks or a little longer and recounted for 300-500 minutes to measure the long-lived radionuclides ${ }^{51} \mathrm{Cr},{ }^{59} \mathrm{Fe},{ }^{60} \mathrm{Co},{ }^{65} \mathrm{Zn}$, ${ }^{203} \mathrm{Hg},{ }^{124} \mathrm{Sb}$ and ${ }^{46} \mathrm{Sc}$. The neutron activated standards had also been counted at appropriate time and compared directly with the samples. For short-lived radionuclides necessary corrections for decay and counting times have been applied.

Figure 1, 2 and 3 show the typical gamma spectra of some irradiated samples at various times after neutron irradiation. Table 1 shows the gamma-ray energy and half life of radionuclides used in these determinations.

\section{Results and Discussion}

Nuclear activation analysis is no doubt a very sensitive technique for determination of a large number of elements. Aside from 


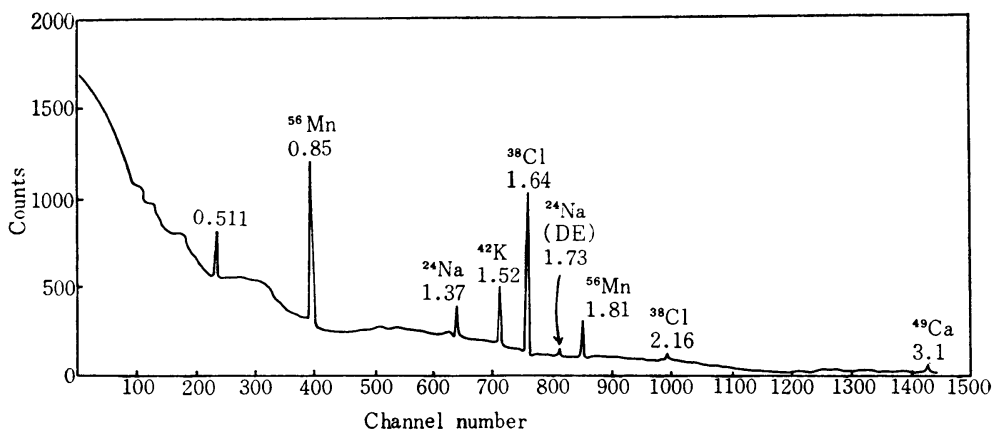

Fig. 1 Typical gamma-ray spectra of tobacco leaves irradiated for 10 minutes and counted for 5 minutes after a decay of 3 minutes.

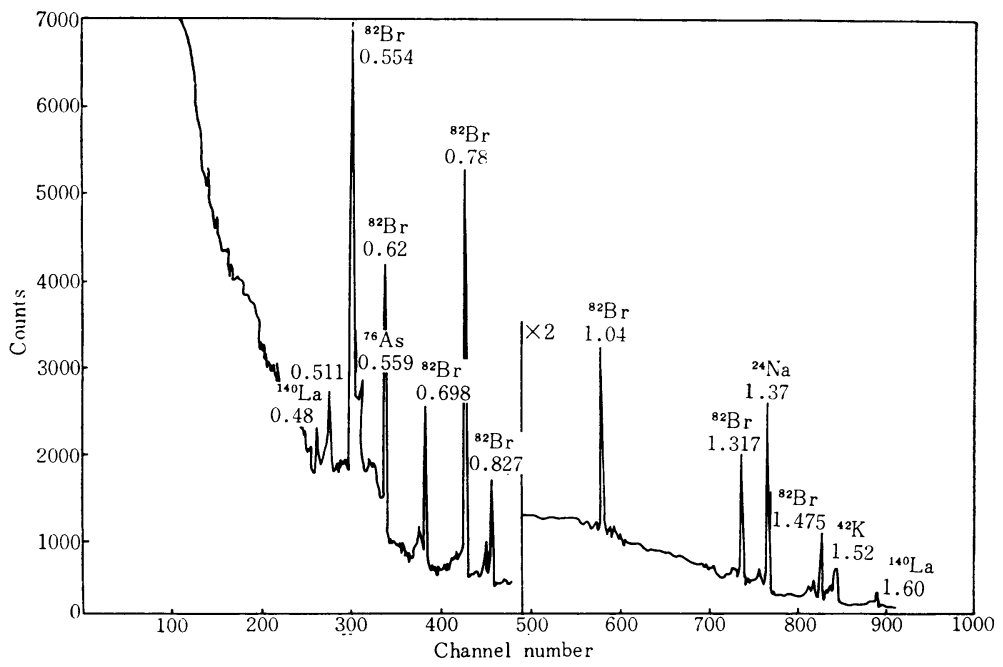

Fig. 2 Typical gamma-ray spectra of tobacco leaves irradiated for 12 hours and counted for 50 minutes after a decay of 3 days.

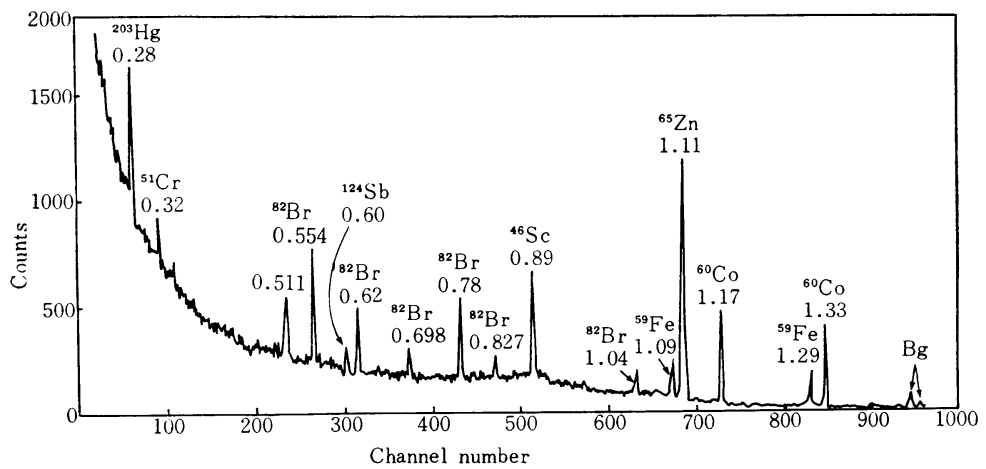

Fig. 3 Typical gamma-ray spectra of tobacco leaves irradiated for 12 hours and counted for 300 minutes after a decay of 15 days. 
Table 1 Energy and half life of the radionuclides under study

\begin{tabular}{l|c|c|c}
\hline \multicolumn{1}{c|}{ Element } & $\begin{array}{c}(n, \gamma) \\
\text { product }\end{array}$ & $\begin{array}{c}\text { Half } \\
\text { life }\end{array}$ & $\begin{array}{l}\gamma \text {-rays used } \\
\text { for analysis } \\
(\mathrm{MeV})\end{array}$ \\
\hline Calcium & ${ }^{49} \mathrm{Cr}$ & $8.8 \mathrm{~m}$ & 3.1 \\
Chlorine & ${ }^{38} \mathrm{Cl}$ & $38 \mathrm{~m}$ & $1.64 ; 2.15$ \\
Manganese & ${ }^{56} \mathrm{Mn}$ & $2.6 \mathrm{~h}$ & $0.845 ; 1.81$ \\
Bromine & ${ }^{82} \mathrm{Br}$ & $35.3 \mathrm{~h}$ & $0.777 ; 0.55$ \\
Iron & ${ }^{59} \mathrm{Fe}$ & $45 \mathrm{~d}$ & $1.29 ; 1.10$ \\
Cobalt & ${ }^{60} \mathrm{Co}$ & $5.2 \mathrm{y}$ & $1.17 ; 1.33$ \\
Zinc & ${ }^{65} \mathrm{Zn}$ & $245 \mathrm{~d}$ & 1.115 \\
Chromium & ${ }^{51} \mathrm{Cr}$ & $27.8 \mathrm{~d}$ & 0.32 \\
Lanthanum & ${ }^{140} \mathrm{La}$ & $40.2 \mathrm{~h}$ & $0.48 ; 1.60$ \\
Arsenic & ${ }^{76} \mathrm{As}$ & $26.4 \mathrm{~h}$ & 0.56 \\
Mercury & ${ }^{203} \mathrm{Hg}$ & $47 \mathrm{~d}$ & 0.28 \\
Scandium & ${ }^{46} \mathrm{Sc}$ & $84 \mathrm{~d}$ & 0.89 \\
Antimony & ${ }^{124} \mathrm{Sb}$ & $60 \mathrm{~d}$ & $0.60 ; 1.70$ \\
\hline
\end{tabular}

factors such as neutron flux, cross section, irradiation time etc., the counting efficiency of detector system is also important in determining the sensitivity of detecting an element. The $\mathrm{Ge}(\mathrm{Li})$ detector is very much superior in energy resolution of $\gamma$-ray spectra, while its detection efficiency is lower than that of $\mathrm{NaI}(\mathrm{Tl})$ detector. Another point that influences the detection limits is mostly due to mutual interferences of isotopes and the Compton continum of higher energetic gamma rays resulted from other isotopes. The present study was aimed to obtain a practical detection limit of each element in the presence of other elements. Table 2 gives the results of the detection limits measured under the criterion in order to validate the peak ${ }^{8)}$ :

$$
\text { peak area } \geq 3 \text { (base area) } \text { (bi }^{1 / 2}
$$

Table 3 shows the results of the determinations of $\mathrm{Cl}, \mathrm{Ca}, \mathrm{Mn}, \mathrm{Br}, \mathrm{Fe}, \mathrm{Co}, \mathrm{Zn}$, $\mathrm{Cr}, \mathrm{La}, \mathrm{Hg}, \mathrm{Sb}$ and $\mathrm{Sc}$ in various kinds of tobacco leaves under investigation. The results are the mean values of at least triplicate runs; the standard deviations being for $\mathrm{Ca}, \mathrm{Cl}$ and $\mathrm{Co} 13 \%$, for $\mathrm{Fe}, \mathrm{Zn}, \mathrm{La}, \mathrm{As}$ and $\mathrm{Sc} 10 \%$, for $\mathrm{Cr}$ and $\mathrm{Mn} 8 \%$, for $\mathrm{Sb} 16 \%$ and for $\mathrm{Hg} \mathrm{4 \%}$, respectively. As can be seen in Fig. 1 through 3, most of photopeaks employed in the analysis were free from spectral interferences. Measurements of long-
Table 2 Detection limits measured for some elements with the instrument used in this experiment

\begin{tabular}{l|c}
\hline \multicolumn{1}{c|}{ Element } & Detection limit (g) \\
\hline $\mathrm{Sc}$ & $10^{-10}$ \\
$\mathrm{Sb}, \mathrm{La}, \mathrm{Mn}, \mathrm{Co}$ & $10^{-9}$ \\
$\mathrm{As}, \mathrm{Hg}, \mathrm{Cr}$ & $10^{-8}$ \\
$\mathrm{Br}, \mathrm{Zn}$ & $10^{-7}$ \\
$\mathrm{Fe}$ & $10^{-6}$ \\
\hline
\end{tabular}

a) $\mathrm{Mn}$ : irradiated for 10 minutes and counted for 10 minutes after a decay of 30 minutes.

b) $\mathrm{Br}, \mathrm{La}, \mathrm{As}$ : irradiated for 12 hours and counted for 50 minutes after a decay of 3 days.

c) The other elements: irradiated for 12 hours and counted for 500 minutes after a decay of two weeks.

lived radionuclides $\mathrm{Fe}, \mathrm{Co}, \mathrm{Zn}, \mathrm{Cr}, \mathrm{Hg}, \mathrm{Sb}$ and $\mathrm{Sc}$ were separated from those of $\mathrm{Br}, \mathrm{La}$ and As after an appropriate decay period so as to avoid large Compton contribution associated with the higher energy gamma rays. The relatively high deviations of $\mathrm{Co}, \mathrm{Cl}, \mathrm{Fe}$, $\mathrm{Ca}$ and $\mathrm{Sb}$ cannot be accounted for merely statistical considerations. Since these elements are usually in a highly mobile form, slight variation in growing conditions and/ or processing could possibly account for these differences. It is of interest to note that, as shown in Table 3 , the mercury contents in tobacco leaves which are locally grown are found in the range of $10^{-7}$ to $10^{-8}$ gram per gram of sample, while those of the imported ones are found to be undetectable under the present detection limit of this study. The trace concentration of elements incorporated in the plant leaves may be due either to the residue of the widespread use of pesticides or to the acquisition of inorganic ions naturally present in the soil through the viscous movement of soil solution or by ionic diffusion to their roots ${ }^{9}$. The results obtained in the present analysis which shows somewhat larger fluctuation in $\mathrm{Hg}$ as well as other trace concentrations of samples coming from different origins may probably be explained on this basis. 
Table 3 Elemental concentration in tobacco leaves determined by instrumental neutron activation analysis

\begin{tabular}{c|c|c|c|c|c|r|}
\hline $\begin{array}{c}\text { Material } \\
\text { analyzed }\end{array}$ & Cr & Co & La & As & Hg & Sb \\
\hline A & $0.31 \pm 0.03$ & $1.03 \pm 0.10$ & $0.24 \pm 0.02$ & $1.14 \pm 0.01$ & $0.141 \pm 0.006$ & $6.73 \pm 0.86$ \\
B & $0.98 \pm 0.05$ & $1.13 \pm 0.14$ & $0.31 \pm 0.02$ & $1.03 \pm 0.08$ & $0.216 \pm 0.005$ & $4.21 \pm 0.46$ \\
C & $1.04 \pm 0.05$ & $0.68 \pm 0.06$ & $0.63 \pm 0.04$ & $2.18 \pm 0.13$ & $0.083 \pm 0.002$ & $10.25 \pm 1.47$ \\
D & $1.13 \pm 0.03$ & $0.34 \pm 0.03$ & $0.27 \pm 0.02$ & $0.96 \pm 0.09$ & $0.172 \pm 0.007$ & $5.78 \pm 0.77$ \\
E & $0.47 \pm 0.03$ & $0.31 \pm 0.02$ & $0.40 \pm 0.02$ & $2.01 \pm 0.16$ & - & $9.41 \pm 0.90$ \\
F & $0.35 \pm 0.03$ & $0.35 \pm 0.05$ & $0.19 \pm 0.02$ & $3.45 \pm 0.29$ & - & $11.0 \pm 1.40$ \\
G & $0.21 \pm 0.02$ & $0.37 \pm 0.04$ & $0.27 \pm 0.02$ & $1.78 \pm 0.11$ & - & $7.85 \pm 1.26$ \\
H & $1.05 \pm 0.06$ & $2.32 \pm 0.02$ & $0.30 \pm 0.02$ & $0.79 \pm 0.05$ & - & $2.49 \pm 0.30$ \\
\hline Material & Zn & \multicolumn{7}{|c|}{ Fe } & Br & Mn & Cl & Ca \\
analyzed & & & & & & \\
\hline A & $36.0 \pm 2.5$ & $189 \pm 17$ & $12.5 \pm 0.7$ & $44.6 \pm 2.2$ & $5,040 \pm 508$ & $40,100 \pm 3,400$ \\
B & $53.4 \pm 3.8$ & $247 \pm 15$ & $42.7 \pm 1.1$ & $41.3 \pm 2.3$ & $2,300 \pm 205$ & $38,300 \pm 3,100$ \\
C & $42.7 \pm 3.4$ & $213 \pm 22$ & $31.5 \pm 1.3$ & $27.8 \pm 1.6$ & $3,140 \pm 370$ & $23,100 \pm 2,400$ \\
D & $28.3 \pm 1.6$ & $178 \pm 11$ & $26.2 \pm 1.2$ & $38.4 \pm 1.8$ & $2,890 \pm 230$ & $46,900 \pm 6,500$ \\
E & $34.6 \pm 2.6$ & $306 \pm 21$ & $49.3 \pm 2.1$ & $39.0 \pm 2.7$ & $4,800 \pm 420$ & $28,600 \pm 2,900$ \\
F & $33.5 \pm 2.7$ & $228 \pm 23$ & $34.8 \pm 1.1$ & $41.7 \pm 3.2$ & $3,670 \pm 530$ & $14,200 \pm 1,800$ \\
G & $46.7 \pm 3.0$ & $192 \pm 13$ & $15.1 \pm 1.0$ & $26.3 \pm 1.7$ & $6,050 \pm 570$ & $76,300 \pm 7,500$ \\
H & $38.3 \pm 6.0$ & $235 \pm 16$ & $32.3 \pm 1.5$ & $40.2 \pm 2.5$ & $2,970 \pm 360$ & $31,100 \pm 3,300$ \\
\hline
\end{tabular}

a) The concentrations in ppm are the mean values of at least triplicate analysis. Error limits are expressed in standard deviation.

b) Samples A, B, C and D are locally grown from the areas of Pington, Hwalien, Chiayi and Taichung in Taiwan, respectively. Samples E and F are imported from the U.S., $\mathrm{G}$ and $\mathrm{H}$ are from Korea and Turkey respectively.

The present study has successfully indicated the feasibility of applying instrumental neutron activation analysis to multielement determination in tobacco leaves. By employing the high resolution $\mathrm{Ge}(\mathrm{Li})$ spectrometer coupled with computerized data reduction system, it was possible to resolve the photopeaks of trace elements of interest to permit the quantitative determination of some 13 elements without resorting to chemical separation.

\section{Acknowledgments}

The authors wish to express their thanks to Taiwan Tobacco and Wine Monopoly Bureau for supplying the tobacco leave samples used in this study. Thanks are also due to Mr. Pin-Yau Chen for his helpful discussion.

\section{References}

1) F. Girardi, G. Guzz and J. Pauly: Radiochim. Acta, 6, 202 (1967)

2) D.C. Camp: UCRL Rept. No. 50156 (1967)

3) C.K. Kim and J. Silverman: Anal. Chem., 37, 1617 (1965)

4) Y. Maruyama, K. Komiya and T. Manri: Radioisotopes, 19, 250 (1970)

5) K. Komiya and Y. Maruyama: Radioisotopes, 20, 29 (1971)

(6) R.A. Nadkarni and W.D. Ehmenn: Modern Trends in Activation Analysis, Nat. Bur. Stand. (U.S.), Spec. Publ. 312, Vol. 1, 190 (1969)

:7) R.A. Nadkarni and W.D. Ehmann: Radiochem. Radioanal. Letters, 4, 325 (1970) 
8) H.P. Yule: Anal. Chem., 38, 103 (1966)

9) C. Dakshinamurti: IAEA Technical Rept.
Series No. 48, "Plant Nutrient Supply and Movement", 57 (1965)

要 旨

\section{中性子放射化分析によるタバコ葉の多種類元素分析}

楊末雄, 頼勝飛, 葉錫溶

清華大学原子科学研究所

タバコの葉について多種類元素を同時に分析するために中性子放射化分析を行なった。電子計算 機による測定データの処理と結びついた高分解能の $\mathrm{Ge}(\mathrm{Li})$ 検出器を用いた。中性子照射してから 適当な冷却期間後に測定することによって, 化学分離をすることなく, タバュの葉で13種の元素 $\left({ }^{49} \mathrm{Ca},{ }^{38} \mathrm{Cl},{ }^{56} \mathrm{Mn},{ }^{82} \mathrm{Br},{ }^{59} \mathrm{Fe},{ }^{60} \mathrm{Co},{ }^{65} \mathrm{Zn},{ }^{51} \mathrm{Cr},{ }^{140} \mathrm{La},{ }^{76} \mathrm{As},{ }^{203} \mathrm{Hg},{ }^{46} \mathrm{Sc},{ }^{124} \mathrm{Sb}\right)$ を定量できた。 この方法による元素の検出限界は Sc $10^{-10} \mathrm{~g} ; \mathrm{Sb}, \mathrm{La}, \mathrm{Mn}, \mathrm{Co} 10^{-9} \mathrm{~g} ; \mathrm{As}, \mathrm{Hg}, \mathrm{Cr} 10^{-8} \mathrm{~g} ; \mathrm{Br}, \mathrm{Zn}$ $10^{-7} \mathrm{~g} ; \mathrm{Fe} 10^{-6} \mathrm{~g}$ であった。タバコ葉に含まれる数種の元素の量はその産地によって変動していた。 